\title{
SAFETY OF EDUCATIONAL ENVIRONMENT: PROFESSIONAL COMPETENCE OF THE FUTURE TEACHER IN COMBATING BULLING
}

\author{
Holovanova T. P. \\ Candidate of Pedagogical Sciences, \\ Assistant Professor at the Department of Pedagogy and Psychology of Educational Activity \\ Zaporizhzhia National University \\ Zhukovskoho str., 66, Zaporizhzhia, Ukraine \\ orcid.org/0000-0003-1202-3720 \\ tatyana1956@gmail.com
}

Key words:

bullying, professional competencies, gender stereotypes, teachers, safety of the educational environment.
The article presents the relationship between the concepts of "safety of the educational environment", "general competencies", "bullying". The urgency and risks of security of the educational environment in the modern conditions of the Ukrainian society are noted. The theoretical foundations of the study of key concepts are revealed through the concepts: security, educational environment, gender stereotypes, online surveys, professional competencies, training criteria.

The experience of the Center for Gender Education of Zaporizhzhia National University has shown that this problem has three aspects: gender, psychological and pedagogical, legal. The gender aspect is revealed through the study of the influence of stereotypes on the perception of the bullying situation by different groups of participants in the educational process. The results of the study of the state of bullying in the student environment are analyzed. The influence of gender stereotypes on behavior in a bullying situation was determined: the procedure was reduced to the choice of high school students, students, teachers, high school teachers of different answers. The results of the study allowed to draw a conclusion about the influence of gender stereotypes on the behavior of boys and girls in a situation of bullying (students, teachers, high school teachers) of different answers. Thus, $40.9 \%$ of surveyed school teachers believed that if a boy in a situation of harassment seeks help from parents, teachers, a psychologist, he is considered, among other answers, "weakling": students $-26.3 \%$; school teachers $-40.9 \%$; university teachers $-15.4 \%$; practical psychologists and social pedagogues of educational institutions of the city $-12.5 \%$.

The process of formation of professional competencies of future teachers was realized through the developed program of master's research. An important task of this study was to develop research criteria. The issues of development of diagnostics of evaluation of work of pedagogical workers on creation of safe educational environment are waiting for further study. 


\title{
БЕЗПЕКА ОСВІТНЬОГО СЕРЕДОВИЩА: ФАХОВІ КОМПЕТЕНТНОСТІ МАЙБУТНЬОГО ВИКЛАДАЧА ЩОДО ПРОТИДІЇ БУЛІНГУ
}

\author{
Голованова Т. П. \\ кандидат педагогічних наук, доиент \\ Запорізький національний університет \\ вул. Жуковського, 66, Запоріжжя, Україна \\ orcid.org/0000-0003-1202-3720 \\ tatyana1956@gmail.com
}

\author{
Ключові слова: \\ булінг, фахові \\ компетентності, гендерні \\ стереотипи, викладачі, \\ безпека освітнього \\ середовища.
}

\begin{abstract}
У статті представлено взаємозв'язок понять «безпека освітнього середовища», «загальні компетентності», «булінг». Зазначено актуальність та ризики безпеки освітнього середовища в сучасних умовах українського суспільства. Теоретичні основи дослідження ключових понять розкриваються через концепти: безпека, освітнє середовище, гендерні стереотипи, онлайн-опитування, фахові компетентності, критерії підготовки.

Досвід центру гендерної освіти Запорізького національного університету показав, що ця проблема має три аспекти: гендерний, психологопедагогічний, правовий. Гендерний аспект розкривається через дослідження впливу стереотипів на сприйняття ситуації булінгу різними групами учасників освітнього процесу. Проаналізовано результати дослідження стану булінгу в студентському середовищі. Визначався вплив гендерних стереотипів дівчат і юнаків на поведінку в ситуації булінгу: процедура зводилася до вибору старшокласниками, студентами, вчителями, викладачами вищої школи різних варіантів відповідей. Результати проведеного дослідження дали змогу зробити висновок про вплив гендерних стереотипів на поведінку юнаків і дівчат у ситуації булінгу (студентами, вчителями, викладачами вищої школи) різних варіантів відповідей. Так, 40,9\% опитаних вчителів шкіл вважають, «якщо хлопець у ситуації цькування звертається по допомогу до батьків, вчителів, психолога, то його вважають, серед інших відповідей, «слабаком»: студенти - 26,3\%; вчителі шкіл - 40,9\%; викладачі вишу $15.4 \%$; практичні психологи та соціальні педагоги освітніх закладів міста - 12,5\%. Процес формування фахових компетентностей майбутніх викладачів було реалізовано через розроблену програму магістерського дослідження. Важливим завданням цього дослідження було розробка критеріїв дослідження. На подальше вивчення чекають питання розробки діагностики оцінювання роботи педагогічних працівників щодо створення безпечного освітнього середовища.
\end{abstract}

Problem statement. The changes taking place in the Ukrainian secondary and higher education, actualize the task of forming the professional competences of future teachers, as subjects of creating a safe and healthy educational environment [1]. A safe educational environment should, in particular, provide a solution to such problems as combating physical, psychological violence and bullying. The growing role of safety in the educational environment requires new research aimed at building professional competence. In such circumstances, the problem of the implementation of the principle of educational envi- ronment's safety, that declared in the official documents of education in Ukraine, becomes especially important. The article was prepared within the framework of a comprehensive program of research work of the Department of Pedagogy and Psychology of Educational Activity "Psychological and pedagogical principles of competence development of subjects of educational space".

Analysis of papers. Analysis of domestic and foreign literature sources shows that scientists have paid and continue to pay considerable attention to the security of the educational environment. The educa- 
tional environment and the safety of the educational environment have been studied by both foreign and domestic researchers. A review of research is presented in the works of G. Vasyanovich [3], L. Makar [4], T. Tsyuman [5]. Problems of bullying, the role of teachers in combating bullying, are considered in the works of modern Zaporizhzhia scientist O. Barlit [6]. The theory of the formation of professional competences of the Master of specialization 011 Educational, pedagogical sciences was considered in the article [7].

Selection of previously unresolved parts, a common problem to which the article is devoted. Despite the growing interest in the study of particular aspects of the educational environment, the problem of safety of the educational environment remains relevant today. In connection with the entry into force in January 2019 of the Law of Ukraine № 2657-VIII “'On Amendments to Certain Legislative Acts of Ukraine on Combating Bullying" [8] future teachers of higher education or other educational institutions must be ready to implement the state policies for the introduction of anti-bullying in the educational environment. In particular, the Law of Ukraine "On Education" is supplemented by the clause, which foresees that bullying is the act (act or omission) of participants in the educational process, which consists in psychological, physical, economic, sexual violence, including the use of electronic communications, committed against a minor or junior and (or) such a person in relation to other participants in the educational process, which could have caused or harmed the victim's mental or physical health [8]. However, nowadays, the system of higher education does not clearly identify the content of professional competencies of future teachers in terms of safety of the educational environment and combating bullying.

Formulation of the aims of the article. The purpose of the article is to analyse the concepts and categories "safety of the educational environment", "bullying", "professional competencies"; to highlight the results of empirical research; to describe the criteria of future teachers' training to combat bullying.

Statement of the basic material. The study of the safety of the educational environment through the prism of the formation of professional competence of the future specialist in combating bullying in educational institutions has its own specifics, as it is carried out on the border of social psychology, theory of children's rights, social pedagogy, management psychology, theory of gender education, theory of competence education.

Therefore, to clearly understand the situation, it is necessary to determine the basic concepts and categories that will be used in the process of considering the topic. The most important concepts are: "bullying", "gender stereotypes", "safety of the educational environment", "professional competence". Analysis of the works of scientists revealed that the term "educational environment" in pedagogy means a set of conditions that affect the formation and functioning of man in society, the visual and human environment of the individual, his abilities, needs, interests, consciousness [4].

According to the authors, "a safe educational environment is a state of the educational environment in which: there are safe learning and working conditions, comfortable interpersonal interaction that contributes to the emotional well-being of students, teachers and parents, no violence and sufficient resources for them, prevention, as well as compliance with the rights and norms of physical, psychological, informational and social security of each participant in the educational process" [5].

Therefore, the issue of trust, friendliness, approval, tolerance is key to the quality of interpersonal relationships. Aggression, conflict, hostility, manipulation are considered risk factors. This problem should be considered, first of all, through the creation of conditions for internal security and the security of the reference environment. And this becomes possible only due to the joint purposeful activities of teachers, students and parents. Thus, security in the educational environment is an assessment of the absence of violence.

One of the risk factors for the safety of the educational environment, scientists and educators, among others, determine the presence of violence, bullying among minors.

There are always three parties involved in a bullying situation: the persecutor; the one who is persecuted and those who watch. Bullying has a negative effect on all participants, their physical and mental health. Bullying can also occur spontaneously when a child suddenly finds himself or herself in a situation of persecution or joins the persecutor. Aggressors are characterized by dominance, low empathy, hyperactivity and impulsivity. It was in the family that they experienced violence and began to pass it on to their peers. This is the "image" of the aggressor, but not the cause of bullying. The cause of bullying/harassment may be prejudice.

Prejudice is a misconception that consists of something or someone in the first place, which determines the appropriate attitude. The experience of research work of the Center for Gender Education of Zaporizhzhia National University has shown that this problem has three aspects: gender, psychological and pedagogical, legal [9]. Gender stereotypes are internal attitudes about the place of men and women in society, their functions and social tasks. Discrimination is that individuals or groups in society may not receive any assistance or rights due to stigma. The formation of stigma occurs at two levels of communication - 
interpersonal and mass. At the first level, a certain position is formed in relation to a particular person or group, sometimes on the basis of a one-time negative experience of interaction. In the second, mass communications play a significant role. Bullying can take many forms. The key characteristic is the system. It creates multiple repetitions and this distinguishes bullying from a single manifestation of aggressive behavior. Based on these provisions, a concept was developed to study the impact of gender stereotypes on student behavior in a bullying situation. In the process of preparation, diagnostic tools were developed to study the impact of gender stereotypes on the behavior of students in a bullying situation.

In turn, the procedure for determining the impact of gender stereotypes on behavior in a bullying situation was reduced to the choice of high school students, students, teachers, high school teachers of different answers in situations. The first situation was: "If a boy in a situation of harassment seeks help from parents, teachers, a psychologist, he is considered:

- a weakling;

- his actions are assessed as correct".

$40.9 \%$ of surveyed school teachers believed that if a boy in a situation of harassment seeks help from parents, teachers, a psychologist, he is considered, among other answers, "weakling": students $-26.3 \%$; school teachers $-40.9 \%$; university teachers $-15.4 \%$; practical psychologists and social pedagogues of educational institutions of the city $-12.5 \%$.

Interesting results were obtained from the answers to the second situation: "Imagine a situation of harassment in which photos of a girl with offensive captions are posted on social networks. Will it be easy for her to seek help from parents, teachers, a psychologist?" "No" answered: $60.5 \%$ of students; $34.5 \%$ of school teachers; $61.5 \%$ of university teachers; $75 \%$ of practical psychologists and social educators of educational institutions of the city.

Thus, the results of this research allowed us to see trends in the impact of gender stereotypes on student behavior in a bullying situation. It can be argued that this knowledge should be implemented in the content of professional training of future teachers.

One of the steps to solve this problem at Zaporizhzhia National University under our leadership, a graduate student of "Higher School Pedagogy" Sitchenko Dina Mykolayivna was prepared and defended a thesis "Preparation of future teachers for anti-bullying programs in education".

One of the tasks of this work was to determine the system of research criteria. The criterion "Initial level of training of future teachers on the problem of bullying and counteraction to this phenomenon" was taken as a basis: three components: values, attitudes, experience of future teachers. The next criterion - "The result of training future professionals to combat bullying in higher education". Such quality, regardless of the specialty and direction of training, is professional competence. This competence was presented through a structured system of knowledge:

- about the concept of «bullying», types and forms of its manifestation; causes and consequences (for the victim (victim), abuser (buller), observers); identification, self-identification of victims of bullying; knowledge of legal documents governing the fight against bullying in educational institutions; mechanism for detection, response, redirection and treatment in a bullying situation; systematic work of the educational institution to combat bullying and the involvement of all participants in the educational process; the place and opportunities of all participants in the educational process in this system; available and possible resources to raise awareness and prevent bullying;

- developing their own attitude to the manifestation of bullying and combating bullying in educational institutions;

- acquisition of skills to implement appropriate forms and methods of combating bullying,

- acquisition of non-violent communication skills related to non-stereotypical perception of a person without prejudices; recognition of values, ways of resolving conflicts and symbolic representations. We consider the content of this competence as a professional competence that depends on the subject area and is important for successful pedagogical activities [2].

Conclusions from this study. There is a relationship between the concepts of "safety of the educational environment", "bullying", "professional competencies". This problem has three aspects: gender, psychological and pedagogical, legal. The gender aspect is revealed through the study of the influence of stereotypes on the perception of the bullying situation by different groups of participants in the educational process. The process of formation of professional competencies of future teachers was carried out, including through the developed criteria. An important criterion was defined - professional competence. The issues of developing diagnostics for evaluating the work of pedagogical staff to ensure a safe environment in the educational institution are awaiting further study. 


\section{References}

1. Pro Natsionalnu stratehiiu rozbudovy bezpechnoho i zdorovoho osvitnoho seredovyshcha u novii ukrainskii shkoli: Ukaz Prezydenta Ukrainy № 195/2020 vid 25 travnia 2020 [On the National Strategy for Building a Safe and Healthy Educational Environment in the New Ukrainian School: Decree of the President of Ukraine] (№ 195/2020, May 25) (2020). URL: https://zakon.rada.gov.ua/laws/show/195/2020.

2. Metodychni rekomendatsii shchodo rozroblennia standartiv vyshchoi osvity [Methodical recommendations for the development of higher education standards]. URL: https://mon.gov.ua/storage/app/media/ vishcha-osvita/proekty\%20standartiv\%20vishcha\%20osvita/1648.pdf.

3. Vasianovych, H.P. (2017) Do poniattia bezpeky osvitnoho seredovyshcha: aspekty doslidzhennia [To the concept of safety of the educational environment: aspects of research]. Zbirnyk naukovykh prats Khmelnytskoho instytutu sotsialnykh tekhnolohii Universytetu «Ukraina» [Collection of scientific works of the Khmelnytsky Institute of Social Technologies of the University «Ukraine»]. Vol. 13. URL: http://nbuv.gov.ua/UJRN/Znpkhist_2017_13_4.

4. Makar, L.M. (2013) Sutnist osvitnoho seredovyshcha v pedahohichnomu protsesi [The essence of the educational environment in the pedagogical process] Pedahohika formuvannia tvorchoi osobystosti u vyshchii i zahalnoosvitnii shkolakh [«Pedagogy of formation of creative personality in higher and secondary schools»] Vol. 30. P. 229-236. URL: http://nbuv.gov.ua/UJRN/Pfto_2013_30_37.

5. Tsiuman T.P., Boichuk N.I. (2018) Kodeks bezpechnoho osvitnoho seredovysh̆cha: metod. posib. / za zah. red. Tsiuman T.P. [Code of safe educational environment: methodical manual/ edited by Tsiuman T.P.]. URL: https://mon.gov.ua/storage/app/media/zagalna\%20serednya/protidia-bulingu/21kbos.pdf.

6. Barlit, O.O. (2016) Neobkhidnist pidhotovky pedahoha v systemi pidvyshchennia kvalifikatsii pedahohichnykh pratsivnykiv do realizatsii systemy efektyvnoi protydii bullinhu v osvitnomu seredovyshchi [The need to train teachers in the system of professional development of teachers to implement a system of effective counteraction to bullying in the educational environment]. Zaporizhzhia : KPU. № 48 (101). P. 299-304.

7. Holovanova, T.P. (2018) Teoretychni zasady profesiinoi kompetentnosti maibutnoho vykladacha vyshchoi shkoly [Theoretical bases of higher school future teachers' professional competence]. Visnyk Zaporizkoho natsionalnoho universytetu. Pedahohichni nauky [Bulletin of Zaporizhzhia National University: Pedagogical Sciences]. № 1(30). P. 68-76. URL: http://nbuv.gov.ua/UJRN/Vznu_ped_2018_1_14.

8. Zakon Ukrainy "Pro vnesennia zmin do deiakykh zakonodavchykh aktiv Ukrainy shchodo protydii bulinhu (tskuvanniu)" [The Law of Ukraine «On Amendments to Some Legislative Acts of Ukraine on Combating Bullying»] (No.2657-VIII, December 18). (2018). URL: https://zakon.rada.gov.ua/laws/show/2657-19.

9. U ZNU provely naukovo-praktychnyi seminar "Profilaktyka bulinhu v uchnivskomu seredovyshchi". [ZNU held a scientific-practical seminar "Prevention of bullying in the student's environment"] URL: https://www.znu.edu.ua/cms/index.php?action=news/view_details\&news_id=45258\&lang=ukr\&news_ code=u-znu-proveli-naukovo-praktichnij-seminar---profilaktika-bulingu-v-uchnivskomu-seredovischi--. 